\title{
Analysing the Works of a Machine Translation
}

\author{
Dedy Setiawan \\ Politeknik Negeri Bandung, Indonesia \\ dedy.setiawan@polban.ac.id
}

DOI: http://doi.org/10.36892/ijlls.v2i2.292

$\begin{array}{ll}\begin{array}{l}\text { Received: } \\ \text { 08/03/2020 }\end{array} & \begin{array}{l}\text { Abstract } \\ \text { Machine translation has been around for years. This application is now used } \\ \text { frequently in social media with texts which are usually short and simple and } \\ \text { found in daily lives. Machine translation has undergone great progress from } \\ \text { the time it was introduced to the public in the early 2000s. However, there has } \\ \text { been no research to see the performance of machine translation. The present } \\ \text { research is intended to analyze the works of machine translation with the } \\ \hline \text { Keywords: }\end{array} \quad \begin{array}{l}\text { objects which are complicated scientific texts as found in journal articles. It is } \\ \text { intended to see if the result of machine translation is comprehensible, } \\ \text { accurate and reliable in translating documents. The result suggests that the } \\ \text { scientific texts; } \\ \text { comprehensible; } \\ \text { accurate; }\end{array} \\ \begin{array}{l}\text { works of machine translation are found to be comprehensible and reliable for } \\ \text { obtaining the meaning of the translated texts, but it does not conform to the } \\ \text { standards for publishable criteria. Further works are needed if the translated } \\ \text { texts are aimed for publication. }\end{array}\end{array}$

\section{INTRODUCTION}

There are some translation machines that have been created, but Google Translation is probably the most commonly used because it is free, easy to use and very handy. It often appears as a ready-for-use application in social media. It also comes as a package of Google application which is available in a computer set when it is connected with Google. This application has been used for various purposes both professional and non-professional but only to a particular extent, that is, to get to understand the meaning of a text. As the application appears in social media, many of them are often used to get the translation of status in social media which is usually short and simple.

People read the translation works instead of the original one mainly because they want to know the content of the work. So, hence the result of translation works should be first seen from the aspect of comprehensibility. However, some would like to use machine translations for other purposes. This certainly requires more than just a comprehensible aspect.

When translating short sentences especially related to daily language expressions, the work result of Google translations looks comprehensible and meets the other requirements for quality although some words or phrases are not properly, completely and grammatically well translated. I put for translation exercises with the machine using a number of daily phrases. The result was good; all of them are understood and comprehensible, but only a few of them are not correctly translated in terms of grammar. This means that the Google translation is reliable for translating simple daily expressions. 
The Purpose of the Research

The Purpose of the present research is to see how machine translation works on longer texts which are complex, scientific and academic. Some research questions are then made as guidance for conducting the research:

- How scientific texts are translated from Indonesian into English by a machine translator and vice versa?

- Are the texts properly translated which result in comprehensible, accurate and reliable principles?

The scope of the research is to see the results of machine translation that use scientific texts. It will look at the quality of the translation in general but not in detail

\section{LITERATURE REVIEW}

Discussion or research concerning translation machine can be traced back to the time in the 1940s when Warren Weaver suggested the use of electronic computers of great capacity, flexibility, and speed for the solution of the world-wide translation problem which later was followed in 1965 when Yehoshua Bar-Hillel uncovered the research for making of Machine translation (MT) which became a multimillion-dollar affair (ALPAC 2019). In the early 2000s, the machine translation known as 'transtool' was very popular and used widely despite the imperfections with its word for word translation principle. However, later it is worth noting to the view that computers should be used as to help humans rather than to replace them in translation (Sommers 2003).

Hutchins (2003 a) uncovers some reasons why a translation machine is needed. The first is about the great number of needs of translations works; the second reason is that translation work is a boring job; third is the need for consistent terminology used in translating documents, hence, a computer is an appropriate tool; the fourth reason is that computer-based translation tools can increase the volume and speed of translation, and the fifth reason is that top quality human translation is not always needed.

Research related to the use of machine translation has been carried out in different contexts. Koehn (2009) investigated how the translator uses a translation tool to translate 192 sentences from French news stories into English. He found that most translators were faster and better when assisted by the tool. Hutchins (2003 b) surveyed the development of machine translation. He tried to find out appropriate translations to meet the present demand and use of computer-based translation software as in controlled language systems, translator workstations, and localization. This research has made a great contribution for the development of machine translation.

While translation is defined as the process of changing words or text from one language into another, other scholars define it in different words. According to Newmark (1981), translation is defined as a capability consisting of the attempt to replace a written message and/or statement in one language by the same message and/or statement in another language. Similarly, Cartford (1969) defines translation as the replacement of textual material in one language (SL) by equivalent textual material in another language (TL). Osman (2017), however, suggests that translation is a mental activity in which the meaning of given linguistic discourse is rendered from one language to another.

From the definitions above, we can conclude that translation is an effort to gain the meaning of one language (usually foreign language) so that the meaning can be conveyed 
into another language (target language). Accordingly, what is translated is the concept of a word from one language to another.

Some translation procedures suggested by Newmark (1981) such as Literal translation; b) Transferensial; c) Naturalization; d) Cultural equivalent; e) Functional equivalent; f) Descriptive equivalent; g) Through translation; h) Shift or Transposition; and i) Temporary translation labels should be the guide for designing the content for the machine translation.

Literal translation, which is present in the translation of words per word, is probably the most frequently used principle in machine translation. While Transferensial is used as it is the process of subtitling from the source language to the target language which includes word loan, adaptation of pronunciation and spelling adjustments, and transliteration related to conversations. Similarly, Naturalization is also used as it is a manifestation of the continued translation of absorption and adjusting spelling and word form (morphology) in the target language.

Cultural equivalent, which is used where the word culture in the source language is translated by the word target culture is similar to Functional equivalent. The latter is a general procedure, applied to cultural words, which requires the use of a culture-free word, sometimes with new scientific terms, then maximizes/neutralizes the word.

Other principles such as Descriptive equivalent, Through translation, Shift or Transposition and Temporary translation labels require special attention as they involve compound words, changes in grammar form such as the shift from singular to plural and new institutional term as well as names of organization. In machine translation, such matters still exist, but they are certainly solvable with further works from linguistic experts'

In another instance, Bosco (2019) points out some translations techniques which derive from two categories, namely, Direct Translation Techniques and Oblique Translation Techniques. The first is used when structural and conceptual elements of the source language can be transposed into the target language. Direct translation techniques consist of Borrowing, Calque and Literal Translation. The latter, Oblique Translation Techniques, are used when the structural or conceptual elements of the source language cannot be directly translated without altering the meaning or upsetting the grammatical and stylistics elements of the target language. Oblique Translation Techniques include Transposition Modulation, Reformulation or Equivalence, Adaptation and Compensation

My pre-assumption is that literal translation will be the most commonly used translation procedure because, like an online dictionary, the machine translates words for words unless there are sub sequential works done for perfection on the machine such as on translation of idioms, phrasal verbs and word phrases.

The latest research on machine translation is about the use of Neural Machine Translation (Luong et al, 2014; Wu et al 2016; Cho et al 2014). Neural machine translation is a relatively new approach to statistical machine translation which is based on neural networks. Interestingly, Philipp K, et al (2007) proposes an open-source toolkit for statistical machine translation called Moses. According to the makers, the toolkit can support for linguistically motivated factors, give confusion network decoding, and make efficient data formats for translation models and language models.

Interestingly, there is a great progress of machine translation with the existence of voice translation such as Voice Translate (2019) and Voice to Voice Translation (2019) and iTranslatevoice3 (2019). Those applications translate simple language expressions that are used in daily conversations so the translation performed sounds perfect. However, no research has been conducted to investigate the performance of such voice translation apps.

From the above literature, we can see that none of them has investigated the result or performance of machine translation. The present research is about a topic that has not been much explored by former researchers. The present research is trying to analyze the works of machine translation especially Goggle translation application which is often used by students 
and academics to translate texts if they have problems with understanding texts. It is also intended to see if the result of machine translation is comprehensible, accurate and reliable in translating documents. It is a concept adopted from Nababan(2008) who suggests that there are three aspects for quality of translation, namely accuracy, readability, and acceptability. While the two aspects of comprehensibility and accuracy are similar to readability and accuracy in the present study, the aspect reliability in my view is more appropriate than acceptability. Reliability is more than acceptable in the parts of the readers, while acceptability is just the acceptance.

\section{MATERIALS AND METHODS}

Text analysis is the main method that is used for the present research. The analysis is conducted on the result of translation performed by a machine translator. It will focus on the comprehensibility, accuracy and acceptability aspects of the translation as suggested earlier.

The following steps show how the present research was conducted:

- Open the application of Google translation;

- Insert the original text on the left column;

- Wait for the translation of the original text;

- Analyze both original and translated texts.

- Analyze the translated text in terms of accuracy, readability, and acceptability;

- Put the result analysis on the table completed with the rate for accuracy, readability and acceptability for each text as in the table below:

In this context, comprehensibility is to see how easy it is for us to understand the text. Accuracy is to find out the appropriateness of rules put in the text; and acceptability is to see if the text is in line with the culture or scientific content that adheres to the text.

A number of scientific texts taken from research articles from various international journals have become the subjects under analysis. The first original texts are Indonesian which are translated into English, and the next text group is English as the original texts which are translated into Indonesian.

\section{RESULTS AND DISCUSSION}

The number of words of the original and translated texts is different. The original text which is Indonesian has a smaller number of words than its English counterpart. This can be seen from the table below. The difference in the number of words from English to Indonesian versions is also significant ranging from about 5 to almost $20 \%$.

Table 1: Size of Texts 1

\begin{tabular}{|c|c|c|c|c|}
\hline $\begin{array}{c}\text { Text } \\
\text { Number }\end{array}$ & Original & Translated & Differences & $\begin{array}{c}\% \text { of } \\
\text { Differences }\end{array}$ \\
\cline { 2 - 5 } (Indonesian) & (English) & & 4.97 \\
\hline 1 & 302 & 317 & 15 & 15.70 \\
\hline 2 & 223 & 258 & 35 & 19.81 \\
\hline 3 & 308 & 369 & 61 & 11.53 \\
\hline 4 & 399 & 445 & 46 & \\
\hline
\end{tabular}


Similar phenomena also happen to the text in which the original text is English and the translation text is Indonesian. From the table below we can see that the English version has more words than Indonesian translation in each text. The difference in the number of words is also significant ranging from 10 to 17 percent.

Table 2: Size of Texts 2

\begin{tabular}{|c|c|c|c|c|}
\hline $\begin{array}{c}\text { Text } \\
\text { Number }\end{array}$ & Original & Translated & Differences & $\begin{array}{c}\% \text { of } \\
\text { Differences }\end{array}$ \\
\cline { 2 - 5 } & (English) & (Indonesian) & & 10.36 \\
\hline 5 & 280 & 251 & 29 & 10.28 \\
\hline 6 & 457 & 410 & 47 & 17.31 \\
\hline 7 & 283 & 234 & 49 & 12.46 \\
\hline 8 & 305 & 267 & 38 & \\
\hline
\end{tabular}

\section{Analysis of Text 1}

The translation is from Indonesian text into English. In the translated version, which is English, the language use is generally comprehensible and acceptable but there is a little lack of accuracy with the translation of singular verb 'iklan' to plural 'advertisements, which is not necessary, and even faulty.

\section{Analysis of Text 2}

The original text is Indonesian and it is translated into English. In general, the text is comprehensible and acceptable but there is a lack of accuracy, which is the misplace of modifier 'baik' to become 'good' in the phrase 'good English'. The word 'baik' in the original text modifies the phrase of 'menulis esai'. So, the text should be translated as 'Good writing essay' or 'Good essay writing'. Another misplaced modifier is in the translation of 'kesalahan bentuk paling mendominasi' which should be translated as 'error form dominated' or 'form of error dominated'.

\section{Analysis of Text 3}

The original text is Indonesian and it is translated into English. In general, the text is comprehensible, accurate and acceptable although there are some expressions that need revision such as the clause 'the essay written by students of the English Study Program is still found many grammatical errors' (sic).

\section{Analysis of Text 4}

The original text is Indonesian and it is translated into English. In general, the text is comprehensible, accurate and acceptable. In the target language, we can hardly find any mistake. This is the text from those under analysis which satisfy the requirements of the three aspects of translation.

\section{Analysis of Text 5}

The original text is English and it is translated to Indonesian. In general, the text is comprehensible, and acceptable but there are some expressions which sound uncommon in Indonesian language such as the clause 'teks sastra tidak bisa terlalu ditekankan' (sic). But it should be the 'role' or 'peran' yang tak bisa terlalu ditekankan - over emphasized. 
The word 'melayani' which is translated from 'to serve' is also inappropriate, It should be translated as 'memenuhi' instead. This also happens to the word 'look beyond; which is translated as 'melihat melampaui' (sic).

\section{Analysis of Text 6}

The original text is English and it is translated into Indonesian. In general, the text is comprehensible, and acceptable, but there are a few notes to make with some inappropriate translation. The word 'is considered' is translated as 'dianggap'. This is not appropriate as according to the context, it should mean 'dibahas' or 'is mentioned. Similarly the phrase 'post-method era' is improperly translated as 'metode pasca kami era' (sic). Then, 'even if' is inappropriately translated as 'bahkan jika' ( $\mathrm{sic}$ ), which should be 'bahkan apabila'. Finally in this text, the word 'on stage' is strangely translated as 'diatas panggung' in the text, which sound funny to Indonesian ears.

\section{Analysis of Text 7}

The original text is English and it is translated into Indonesian. In general, the text is comprehensible, and acceptable, but there is a note that needs to be made. The word 'methods' is translated as 'metode'. It is not appropriate because the number of methods is more than one. So it should be translated as in plural form: 'metode metode', which in Indonesian the plural form is expressed by repeating the word twice.

\section{Analysis of Text 8}

The original text is English and it is translated to Indonesian. In general, the text is comprehensible, and acceptable, but there is a note that needs to be made as in: The phrase 'Both second year females and males' is inappropriate and uncommon in Indonesian language, translated as 'Baik perempuan dan laki-laki tahun kedua' (sic). According to the context, it should be translated as 'Siswa kelas dua baik laki laki maupun perempuan'. So, there is a misplace of word translation.

From the analysis above, we can find that all texts are generally well-translated considering the aspects of comprehensibility and acceptability. Only some phrases which were not appropriately translated because the machine does not consider the context properly.

The following table illustrates the summary of analysis of the 8 results of machine translation.

Table 3: Summary of Analysis

\begin{tabular}{|l|l|l|}
\hline \multicolumn{1}{|c|}{$\begin{array}{c}\text { Text } \\
\text { No }\end{array}$} & \multicolumn{1}{|c|}{ Result of Analysis } & \multicolumn{1}{c|}{ Notes } \\
\hline 1 & CA,but no Accuracy with Should be singular & $\begin{array}{l}\text { Comprehensible and } \\
\text { Acceptable with a little } \\
\text { note }\end{array}$ \\
\hline 2 & $\begin{array}{l}\text { CA but lack of accuracy } \\
\text { Wrong place of modifier. }\end{array}$ & $\begin{array}{l}\text { Comprehensible and } \\
\text { Acceptable with a little } \\
\text { note }\end{array}$ \\
\hline 3 & $\begin{array}{l}\text { CAA the mistake is because of the wrong spelling of } \\
\text { the original }\end{array}$ & $\begin{array}{l}\text { Comprehensible and } \\
\text { Acceptable with a little } \\
\text { note }\end{array}$ \\
\hline 4 & CAA & Comprehensible and \\
\hline
\end{tabular}




\begin{tabular}{|l|l|l|}
\hline & $\begin{array}{l}\text { Found almost no mistakes } \\
\text { Acceptable with a little } \\
\text { note }\end{array}$ & $\begin{array}{l}\text { CA except for choice of words (Ditekankan should be } \\
\text { diharapkan; melayani should be memenuhi. } \\
\text { CA but some words are not translated: Literariness }= \\
\text { kesusastraan (=hal ini); laten = penting } \\
\text { CAA but the word look over is translated as } \\
\text { melampaui. It should be 'lebih dari sekedar' } \\
\text { Acceptable with a few } \\
\text { notes }\end{array}$ \\
\hline 6 & $\begin{array}{l}\text { CAA but } \\
\text { The words considered should be translated as } \\
\text { 'dibahas'; post method era should be translated as } \\
\text { 'era sesudah metode'. } \\
\text { CA but even if is translated as bahkan jika; I think it } \\
\text { should be bahkan 'apakah suatu kegiatan yang } \\
\text { disajikan akan bekerja dalam konteks mereka sendiri } \\
\text { atau tida'.. } \\
\text { CAA but The 'stage' as membawa para siswa (yang } \\
\text { belajar) untuk pentas melakukan tugas etc ... }\end{array}$ & $\begin{array}{l}\text { Comprehensible and } \\
\text { notes }\end{array}$ \\
$\begin{array}{l}\text { CAA but there are unnecessary capitalizations; the } \\
\text { words 'methods' should be translated as 'metode- } \\
\text { metode'. }\end{array}$ & $\begin{array}{l}\text { Comprehensible and } \\
\text { Acceptable with a little } \\
\text { note }\end{array}$ \\
\hline 7 & $\begin{array}{l}\text { CA but dan should be translated as maupun. } \\
\text { Comprehensible and } \\
\text { Acceptable with a little } \\
\text { note }\end{array}$ \\
\hline 8
\end{tabular}

From the table above, we can see that all of the texts both from Indonesian to English and vice versa are well translated. The result of the translation is both comprehensible and acceptable with few notes for better style of English writing.

\section{Discussion}

The work of machine translation has been well developed now. There has been a great and significant development since its first introduction back in the 1990's. In the early years, machine translation was totally like 'word for word' translation where the position of a word translated is exactly on the place where the word is put in the original version. So, when an original sentence is like 'Ini computer bagus' or 'Dia orang baik' would be translated as in'This computer good' (sic) and 'He person good' (sic).

There have been a lot of great efforts made in English to Indonesian and vice versa of the machine translation especially on compound words, idiomatic expressions and sentence patterns. In Bahasa Indonesia, a compound which usually consists of two or three words is begun with the main word and followed by the modifier as in meja hijau, kucing hitam, and jalan lurus. In the present machine translation such words have been perfectly translated as can be seen in these words:

- Prodi Bahasa Inggris = English Study Program (text 2)

- $\quad$ penggunaan strategi yang efektif = effective strategy $($ text 1$)$

- language learning = pembelajaran bahasa (text 6)

- present study = Penelitian ini (text 5) 
Here, we can see the reduction of a number of words of the compound word translation. There is the elimination of unnecessary words of the compound as in the phrase 'effective strategy'.

Idiomatic expressions, or set expressions, which may consist of two or more words, have now been perfectly translated with acceptable phrases which are commonly used in the target language. The following are examples of such phrases.

- $\quad$ oleh karena itu $=$ therefore $($ text 1$)$

- $\quad$ keterampilan memecahkan masalah $=$ problem solving skills (text 4)

- $\quad$ according to $=$ menurut $($ text 5$)$

- deals with $=$ membahas $($ text 7)

In sentence patterns or other grammatical structures, the result of machine translation is also outstanding. The following are examples of translation with proper grammar or sentence structures.

- Proses rekrutmen merupakan salah satu bagian terpenting dalam manajemen sumber daya manusia. $=$ The recruitment process is one of the most important parts in human resource management. (text 1)

- Sebagian besar industri mengharuskan pelamar kerjanya menguasai dan mahir berbahasa Inggris dengan baik dan dapat menggunakannya untuk berkomunikasi $(45,2 \%) .=$ Most industries require that job applicants mastery and are proficient in English well and can use it to communicate (45.2\%). (text 4).

- The article deals with inclusive education of teenagers with special needs in the United States of America. = Artikel ini membahas pendidikan inklusif bagi remaja dengan kebutuhan khusus di Amerika Serikat. (text 7)

- On the other hand, female students showed a sort of negative reaction to the units included in the fields of function and geometry. = Di sisi lain, siswa perempuan menunjukkan semacam reaksi negatif terhadap unit-unit yang termasuk dalam bidang fungsi dan geometri. (text 8)

There is a great major development of the machine translation now compared to the time when I conducted a limited analysis of the machine translation works (Setiawan, 2003). This development has happened through research with emphasis on translation of idiomatic expressions and compound words as these parts of vocabulary buildings contribute to the perfection of machine translation and avoid the word for word translation as the initial feature of the machine translation.

With the great progress especially on the inclusion of the translation of idiomatic expressions and compound words, the present machine translation cannot be categorized as using 'word for word' procedure as I presumed before. However, as the number of such expressions and words is great, there is a need to be done further for such translation to be included in the machine. This also calls for the translation of cultural words that accorting to Newmark (1981) requires similar translation of the cultural word in the target language. It is lso important to consider the translation of proverb as it is the extraction of the experiences of peoples in life. Proverbs bear cultural messages besides deep meaning as well as wisdoms and some advice. (Assaqaf, 2019, p. 73)

From the accounts above, we can see that the works of machine translation have developed significantly in the last decade. The texts translated are generally comprehensible and acceptable. For the purpose of understanding the texts, the translated works are 
sufficient: it can make the readers understand the text. However, for the purpose of publication of the translated texts, there are a lot of efforts that need to be done. Human touch is still required in machine translation. Accordingly, the present research confirms the previous research that shows machine translation still requires the help of human translators (Hutchins 2001; Ulitkin 2013).

\section{CONCLUSION}

The machine translation works have been proved to be reliable for comprehensibility. For simple utterances or for daily communication, they are more than just comprehensible but even acceptable. This can be seen from the audio translation which now has been marketed and used worldwide. This is very useful for tourists who travel to the countries the language of which they cannot speak or even understand. However, research is required to see the performance of the voice translation. This certainly is beneficial for the improvement of the tool.

For written text with greater complexity as in scientific texts which are often found in journal articles, the translations' works are helpful for acquiring the meaning of the texts. For publication purposes, as the texts should conform to the rules of language standards, a lot of additional work such as editing is required. The machine translation requires higher linguistic knowledge to make the text meet the publication standards.

Research on the analysis of the result of machine translation is always required from time to time. This will help the translation machine maker or designer obtain an input or hint regarding the machine. There are still a lot of Indonesian idiomatic expressions, vocabulary, compound words and even proverbs which still are not yet adequately translated. Time goes by and so does the language: a new word comes so does a new expression along with the development of knowledge, civilization and technology. The machine translation has to be updated to catch up with such development. This needs expertise on both English and Indonesian language which can make the machine translation possible to undertake the progress for the perfection of the works of machine translation

As machine translation works are not only concerned with English and Indonesian language, research with a similar design can be applied to other World languages. Then see the performance of the machine translation whether the result is similar to the present research.

\section{REFERENCES}

Assaqaf, T. (2019). Techniques for Interpreting English Proverbs into Arabic International Journal of Languge and Literary Studies 1(1), 2019, (72 - 80) https://doi.org/10.36892/ijlls.v1i1.27

ALPAC - Automatic Language Processing Advisory Committee (1966). Language And Machines Computers In Translation And Linguistics, National Academy of Sciences National Research Council https://www.nap.edu/resource/alpac lm/ARC000005.pdf

Bosco, G. (2019). Translation Techniques, Interpro Translation Solution, https://www.interproinc.com/blog/translation-techniques. Retrieved June 19, 2019.

Catford, J.C. (1969). A Linguistics Theory of Translation, Oxford: Oxford University Press. 
Cho, K., Van Merrienboer, B., Gulcehre, C., Bahdanau, D., Bougares, "F., Schwenk, H., Bengio, Y., (2014). Learning phrase representations using rnn encoder-decoder for statistical machine translation. arXiv:1406.1078. https://arxiv.org/pdf/1702.05747.pdf?source=post_page

Cho, K, Merrienboer, B., Bahdanau, and Bengio, Y. (2014). On the properties of neural machine translation: Encoder-decoder approaches. arXiv preprint arXiv:1409.1259, https://arxiv.org/pdf/1406.1078v3.pdf

Hutchins, J (2001). Machine translation and human translation: in competition or in complementation? International Journal of Translation, http://www.hutchinsweb.me.uk/IJT2001.pdf

Hutchins, J. (2003 a). Machine translation and computer-based translation tools: what's available and how it's used, http://www.hutchinsweb.me.uk/Valladolid-2004.pdf

Hutchins, J. (2003 b). The Development and Use of Machine Translation Systems and Computerbased Translation Tools, International Journal Of Translation 15 (1), Jan-June 2003, (5 - 26) http://www.hutchinsweb.me.uk/Beijing-1999.pdf

iTranslatevoice3 (2019). iTranslatevoice, http://itranslatevoice.com/ accessed 14 July 2019

Koehn, P (2009). A process study of computer-aided translation, Mach Translat (2009) 23:241-263 DOI 10.1007/s10590-010-9076-3.

Luong, M.T, Pham, H., Manning, C.D. (2014). Effective Approaches to Attention-based Neural Machine Translation, http://nlp.stanford.edu/projects/nmt. Retrieved July 52019

Nababan, M. R. (2008). Kompetensi penerjemahan dan dampaknya pada kualitas terjemahan; pidato pengukuhan guru besar penerjemahan pada fakultas sastra dan seni rupa universitas sebelas maret. Scientifi Paper presented at Open Academic Senate Meeting of Universitas Sebelas Maret Surakarta on 19 April 2008

Newmark, P (1981). Approach To Translation, Oxford: Pergamon Press, Ltd,

Osman, Amira. (2017). Definition of Translation. https://translationjournal.net/October2017/definition-of-translation.html/. Retrieved June 19, 2019

Philipp K, et al (2007). Moses: Open Source Toolkit for Statistical Machine Translation. Proceedings of the ACL 2007 Demo and Poster Sessions, (177-180) Prague, June 2007. Association for Computational Linguistics

Setiawan, D. (2003). Translation as a Means to Transfer the Information, Knoeledge and Culture, proceeding paper of the Kongres Nasional Penerjemah Indonesia, 15 - 16 September 2003, Universitas Sebelas Maret Surakarta.

Sommers, H. (2003). Computers and Translations, Amsterdam: John Benjamins Publishing Company.

Voice Translate (2019). Voice Translate App Review , https://www.youtube.com/watch?v=b9pkGZL1-os. Retrieved June 192019

Voice To Voice Translation (2019). Voice To Voice Translation, https://www.v2vtranslate.com/ Retrieved June 192019.

Ulitkin, I (2013). Human Translation vs. Machine Translation: Rise of the Machines, Translation and Computers Journal 17 (1). https://translationjournal.net/journal/63mtquality.htm

Wu, Y, Schuster, M, Chen, Z, Le, Q.V, Norouzi, M, et al (2016). Google's neural machine translation system: Bridging the gap between human and machine translation. arXiv preprint arXiv:1609.08144, https://arxiv.org/pdf/1609.08144.pdf 


\section{AUTHOR'S BIO}

Dedy Setiawan is a lecturer at Politeknik Negeri Bandung, Indonesia. He got his bachelor's degree from English Department at UPI Bandung. He had his MA and MEd from Victoria University of Wellington, New Zealand and his Ph.D. from Victoria University Melbourne, Australia. 
APPENDIX

The meta-pragmatic information accompanying the speech acts

\begin{tabular}{|c|c|c|}
\hline Linguistic Realization & Explanation & Source \\
\hline $\begin{array}{l}\text { A: Can you ___ please? } \\
\text { B: Yes, sure. }\end{array}$ & making and responding to a request & Volume 1, p.27 \\
\hline $\begin{array}{l}\text { A: Would you like to } \\
\text { B: Yes, I'd love to./Oh sorry, I } \\
\text { can't. }\end{array}$ & $\begin{array}{l}\text { and 'making and responding to a } \\
\text { suggestion' as }\end{array}$ & \\
\hline Should/shouldn't & for advices & Volume 1 p 67 \\
\hline Will/won’t & for intentions & Volume 1 p 67 \\
\hline Must & for an order & Volume 2, p.19 \\
\hline Can & $\begin{array}{l}\text { we use can to talk about ability in the } \\
\text { present }\end{array}$ & Volume 12, p.59 \\
\hline Will & $\begin{array}{l}\text { for future, future possibility } \\
\text { we use will }+V \text { to talk about actions we } \\
\text { think are likely to happen in the future }\end{array}$ & Volume 2, p. 41 \\
\hline Might & $\begin{array}{l}\text { We use might }+\mathrm{V} \text { to talk about actions that } \\
\text { are possible in the future (We are not sure } \\
\text { that if they will happen or not) }\end{array}$ & Volume 2, p.42 \\
\hline Could & we use could to talk about ability in the past & Volume 12,p.60 \\
\hline Will be able to & we use be able to talk about future ability & Volume 2, p.61 \\
\hline And, but, so, because, although & $\begin{array}{l}\text { conjunctions are used to connect words and } \\
\text { ideas }\end{array}$ & Volume 2, p. 10 \\
\hline Wh-questions & $\begin{array}{l}\text { Each question is used for a specific piece of } \\
\text { information }\end{array}$ & Volume 2, Unit 7, p.9 \\
\hline $\begin{array}{l}\text { It's chewing gum } \\
\text { Chew it. } \\
\text { Don't swallow it. } \\
\text { Remember! } \\
\text { Positive: V } \\
\text { Negative: Don't + V. }\end{array}$ & $\begin{array}{l}\text { You use imperatives to tell somebody to do } \\
\text { something, or to give a direct order }\end{array}$ & \\
\hline $\begin{array}{l}\text { To make sb/sth do sth } \\
\text { To cause sth }\end{array}$ & To express effects & Unit 11, p. 49 \\
\hline $\begin{array}{l}\text { Firstly, secondly, next, then, } \\
\text { finally etc. }\end{array}$ & $\begin{array}{l}\text { Connectors are phrases or words used to link } \\
\text { one idea to another. There are many kinds of } \\
\text { connectors. Firstly, secondly, next, then, } \\
\text { finally etc. are used to show a sequence. }\end{array}$ & Unit 11, p.55 \\
\hline
\end{tabular}

